\title{
Food shortage in Zimbabwe: Can wild cereal grains be an alternative source of nutrition?
}

\author{
K. Chitindingu ${ }^{1,2^{*}}$, M.A.N Benhura ${ }^{1}$ and M. Muchuweti ${ }^{1}$ \\ ${ }^{1}$ Department of Biochemistry, University of Zimbabwe, M. P. 167, Mount Pleasant, \\ Harare, Zimbabwe. \\ ${ }^{2}$ Department of Biotechnology, Chinhoyi University of Technology, Chinhoyi, Zimbabwe.
}

*Corresponding author. E-mail: kchitindingu@gmail.com. Tel: +263 772970 244. Fax: +263 4 308046.

\section{ABSTRACT}

Cereals are used as staple food in most countries all over the world including Zimbabwe. Unfortunately, poor rainfall patterns have hampered the production of traditional cereals like maize and wheat leading to poverty especially in third world countries. Five wild cereal grains namely; Amaranthus hybridus, Brachiaria brizantha, Panicum maximum, Rottiboellea cochinchinensis and Sorghum arundinaceum were studied to determine their nutritional value because of their drought tolerance. Two domesticated cereals were used for comparison. The macro nutrients determined were proteins, carbohydrates, fats and minerals. Amaranthus hybridus, a wild cereal, had the highest protein and fat content of $21.44 \%$ and $11.50 \%$ respectively, compared to all the other cereal grains. Brachiaria brizantha had the highest fibre content of $30.34 \%$ while the red variety of Sorghum bicolor had the least fibre content of $2.51 \%$. Phosphorus was detected in all the cereal grains studied. Calcium was detected in all the cereal grains except in red variety of Sorghum bicolor. The nutritional composition of the cereal grains makes them potential alternative food sources.

\section{Keywords}

wild cereals; nutritional composition; Amaranthus hybridus; protein; fibre; minerals.

\section{Academic Discipline And Sub-Disciplines}

Food Analysis

\section{SUBJECT CLASSIFICATION}

Biochemistry Subject Classification

\section{TYPE (METHOD/APPROACH)}

Experimental study

\section{Council for Innovative Research}

Peer Review Research Publishing System

Journal: Journal of Advances in Chemistry

Vol. 7, No. 2

editor@cirworld.com

www.cirworld.com, member.cirworld.com 


\subsection{INTRODUCTION}

The staple foods in the average African diet are cereals, roots, tubers and to a less extent, animal products [9]. Cereals supply 46 percent of the energy requirements while roots and tubers supply 20 percent and animal products cater for only 7 percent of the energy requirements in an average African diet. The dependence of the developing countries on starch based foods as a protein source accounts in part, for protein deficiency which prevails among the population as recognized by Food and Agricultural Organization [1]. In Africa where the daily diet is dominated by starchy staple foods, vegetables and cereals are the cheapest and most readily available sources of nutrients [1]. Cereal foods are important components of the daily diet, providing carbohydrates, proteins, dietary fibers and vitamins. Epidemiological studies have indicated protective role of whole grain foods against several diseases associated with westernized societies such as type 2 diabetes [18,19], cardiovascular diseases [11] and certain cancers [14].

Cereal grains are grown in greater quantities worldwide than any other type of crop and provide more food energy to the human race compared to other crops. In the poorest families in Zimbabwe, cereal food is almost entirely their source of nutrition and the main reason for a cereal dominated diet may be because other sources of nutrition like meat are very expensive [20]. Farming of traditional cereal grains like maize has been hampered by poor rainfall patterns, hence the focus of this research, on the macro-nutritional composition of selected drought resistant wild cereal grains found in Zimbabwe. Recent use of cereals for energy production, for example by fermentation yielding biofuel, has added on the food burden due to competition between energy and food industries. One of the fundamental tasks of modern agriculture is to ensure sufficient food supplies.

Amongst other nutrients, cereal grains contain phenolic compounds that have antioxidant properties [5]. Phenolic compounds are the most abundant antioxidants in the human diet [15]. In addition to their antioxidant properties, phenolic compounds have biological activities such as prevention of age related illnesses like cancer and coronary heart disease [28]. Natural antioxidants are able to protect the human body from free radicals and retard the progress of many chronic diseases.

\subsection{MATERIALS AND METHODS}

\subsection{Collection of samples}

Samples of wild and domesticated cereal grains were collected from Harare and Buhera districts of Zimbabwe. The cereal grains used for the study are listed in table 2.1. The cereal grains were weighed and dried in the shade. The dried samples were ground to a powder using a mill, at the Institute of Mining Research (IMR), University of Zimbabwe and stored in brown bottles away from sunlight for further use.

Table 2.1 Cereal grains used in the study

\begin{tabular}{|c|c|c|c|}
\hline Latin & English & Shona & Family \\
\hline Amaranthus hybridus L. & $\begin{array}{l}\text { smooth amaranth, smooth pigweed, red } \\
\text { amaranth, or slim amaranth }\end{array}$ & $\begin{array}{l}\text { bonongwe, mowa } \\
\text { dhongi, mowa guru }\end{array}$ & Amaranthaceae \\
\hline $\begin{array}{l}\text { Brachiaria brizantha (Hochst. ex } \\
\text { A. Rich.) Stapf. }\end{array}$ & $\begin{array}{l}\text { beard grass, palisade grass, palisade signal } \\
\text { grass, signal grass }\end{array}$ & zinyaruzoka & $\begin{array}{l}\text { Poaceae (alt. } \\
\text { Gramineae) }\end{array}$ \\
\hline Panicum maximum Jacq. & guinea grass, buffalograss & $\begin{array}{l}\text { chitseretsere, } \\
\text { chivavane }\end{array}$ & $\begin{array}{l}\text { Poaceae (alt. } \\
\text { Gramineae) }\end{array}$ \\
\hline $\begin{array}{l}\text { Rottiboellea cochinchinensis } \\
\text { (Lour.) Clayton }\end{array}$ & itchgrass, guinea fowl grass & Mulungwa (Tonga) & $\begin{array}{l}\text { Poaceae (alt. } \\
\text { Gramineae) }\end{array}$ \\
\hline $\begin{array}{l}\text { Sorghum arundinaceum * (Desv.) } \\
\text { Stapf. }\end{array}$ & common wild sorghum & mapfunde emusango & $\begin{array}{l}\text { Poaceae (alt. } \\
\text { Gramineae) }\end{array}$ \\
\hline Eleusine corocana (L.) Gaertn. & Finger Millet & rukweza & $\begin{array}{l}\text { Poaceae (alt. } \\
\text { Gramineae) }\end{array}$ \\
\hline $\begin{array}{l}\text { Sorghum bicolor (Red variety) (L.) } \\
\text { Moench }\end{array}$ & & mapfunde matsvuku & $\begin{array}{l}\text { Poaceae (alt. } \\
\text { Gramineae) }\end{array}$ \\
\hline
\end{tabular}




\subsection{Nutritional analysis}

\subsubsection{Determination of Ash}

A clean labeled crucible was placed in a muffle furnace at $600{ }^{\circ} \mathrm{C}$ for $1 \mathrm{~h}$. The crucible was transferred to a desiccator using metal tongs and allowed to cool before measuring its weight. The sample $(2 \mathrm{~g})$ was transferred into the weighed crucible and placed back into the muffle furnace at $600{ }^{\circ} \mathrm{C}$ for $24 \mathrm{hrs}$. The crucible and its contents were moved into a desiccator to cool to room temperature. The crucible and its contents were weighed and percentage ash was calculated as shown below:

$$
\text { Ash (\%) }=\text { (weight of Ash / weight of sample) } \times 100
$$

\subsubsection{Determination of crude protein}

The sample $(2 \mathrm{~g})$ was transferred into an $800 \mathrm{ml}$ Kjeldahl flask containing $25 \mathrm{ml}$ of sulphuric acid, $10 \mathrm{~g}$ of catalyst mixture and some porcelain boiling chips. The flask and its contents were placed on a digestion rack of the Kjeldahl apparatus and the heat turned on as well as the exhaust fan. Gentle heat was applied for a start until frothing ceased then the flask was subjected to strong heating until the solution was clear. Digestion was continued for 30 minutes. The contents of the flask were allowed to cool. Before the contents solidified, $300 \mathrm{ml}$ of cold distilled water was added with stirring while cooling under running water. In a separate $250 \mathrm{ml}$ Erlenmeyer flask, $50 \mathrm{ml}$ of boric acid and three drops of bromocresol green (indicator) was added and the flask placed such that the tip of the delivering tube from the condenser of the distillation unit dipped into the solution. To the Kjeldahl flask, a few pieces of mossy zinc and $100 \mathrm{ml}$ of $40 \% \mathrm{NaOH}$ were added with the flask tilted so that the reagents ran down the side to the bottom of the flask forming a separate layer. With the stopper on, the contents were gently mixed and fitted on the Kjeldahl apparatus. Heat was applied until there was an accumulation of $200 \mathrm{ml}$ of solution on the receiving flask with boric acid. The collected solution was titrated with $0.1 \mathrm{M} \mathrm{HCl}$. The end point was reached when the indicator solution turned purple from green. The blank contained reagents only and the titre value was subtracted from the sample value. The crude protein was calculated as follows:

Nitrogen $(\%)$ of sample $=[($ volume of acid titrated - volume of blank titrated $) \times($ Acid $M$ sample $(\mathrm{g})$

Crude protein $(\%)=\mathrm{N} \% \times 6.25$

\subsubsection{Determination of crude fibre}

The ground sample $(3 \mathrm{~g})$ was defatted by washing with portions of petroleum ether $(25 \mathrm{ml})$. The defatted dried sample was placed in a long necked $500 \mathrm{ml}$ digestion flask. Two drops of octyl alcohol were added and $200 \mathrm{ml}$ of $1.25 \%$ sulphuric acid were siphoned into the same flask. The flask was attached to a finger condenser and boiled gently for 30 minutes rotating the flask at 5 minute intervals to prevent the sample from sticking to the sides of the flask. At the end of the acid digestion, the contents of the flask were filtered through a Whattman No. 1 filter paper and the residue was washed with $200 \mathrm{ml}$ of hot $1.25 \% \mathrm{NaOH}$. The solution was boiled gently for 30 minutes as before and the second solution (25 ml) was filtered through to a sintered glass crucible with zero porosity and attached to a vacuum pump apparatus using gentle suction. The sample was washed with boiling water, $1 \% \mathrm{HCl}$ and again with boiling water and finally 3 times with petroleum ether. The sample was dried in an oven at $105^{\circ} \mathrm{C}$ overnight. The sample was cooled to room temperature in a desiccator and the weight of the contents was recorded. The contents of the crucible were ignited in a muffle furnace at $550^{\circ} \mathrm{C}$ to $600^{\circ} \mathrm{C}$ for 6 hrs. The crucible was cooled in a desiccator to room temperature and weighed. The loss in weight was recorded as crude fibre and the percentage was calculated as below:

Crude fibre $(\%)=($ loss in weight on ignition / weight of sample) $\times 100$

The weight of sample is the weight before drying and ether extraction.

\subsubsection{Determination of Calcium and phosphorus}

A sample weighing $3 \mathrm{~g}$ was dried to ash in a muffle furnace at $600^{\circ} \mathrm{C}$ for $5 \mathrm{hrs}$. To the ash, $10 \mathrm{ml}$ of $\mathrm{HCl}$ was added followed by $15 \mathrm{ml}$ of distilled water. The mixture was evaporated to $10 \mathrm{ml}$ on a hot plate at $100^{\circ} \mathrm{C}$. The resultant concentrate was cooled and filtered through Whatman filter paper Number 40 (Hardened ashless) into volumetric flasks. The ash was used for the determination of calcium and phosphorus.

\subsubsection{Determination of Calcium}

A $5 \mathrm{ml}$ aliquot of the ash solution was transferred into centrifuge tubes containing saturated ammonium oxalate. A drop of methyl red indicator was added and $\mathrm{pH}$ was adjusted to 5 (faint pink colour of the indicator) using dilute $\mathrm{HCl}$ and $\mathrm{NH}_{4} \mathrm{OH}$. The contents were thoroughly mixed and let to stand for $1 \mathrm{~h}$ followed by centrifugation at 3000 rpm for 5 minutes. The supernatant was discarded and the residue was resuspended as above and centrifuged again, discarding the supernatant. The final residue was dissolved in $10 \mathrm{ml}$ of $\mathrm{HCl}$ and transferred into a $100 \mathrm{ml}$ conical flask before adding $30 \mathrm{ml}$ of distilled water. Magnesium sulphate standard solution $(5 \mathrm{ml})$ was added followed by 5 drops of Eriochrome-Black-T indicator (EBT) and $10 \mathrm{ml}$ buffer solution (ammonium chloride/ammonium hydroxide). The mixture was titrated with EDTA standard and calcium concentration was calculated as below: 
$1 \mathrm{ml} \mathrm{Ca}^{2+}=1 \mathrm{mg} \mathrm{Ca}^{2+}=\mathrm{y} \mathrm{ml}$ of EDTA (concentration of $\mathrm{Ca}^{2+}$ standard is $1 \mathrm{mg} / \mathrm{ml}$ )

$\mathrm{Ca}(\%)=[($ EDTA equiv to $5 \mathrm{ml}$ Ash $\times 20$ (d.f.)) $/$ mass of sample $] \times 100$

\subsubsection{Determination of Phosphorus}

A $1 \mathrm{ml}$ aliquot of the ash sample was placed into a $50 \mathrm{ml}$ volumetric flask containing $25 \mathrm{ml}$ of distilled water and $5 \mathrm{ml}$ of ammonium molybdate reagent. The contents were mixed thoroughly in $2 \mathrm{ml}$ of 2-naphthol-4-sulphonic acid (ANSA reagent). The absorbance of the solution was measured using a Spectronic $20 \AA$ Genesys ${ }^{\mathrm{TM}}$ spectrophotometer at $630 \mathrm{~nm}$ after 20 minutes of adding ANSA reagent. The blank contained regents only and no sample. The concentration of phosphorus was calculated by extrapolation from a standard curve and percentage values were obtained as follows:

Phosphorus $(\%)=[(\mathrm{P} \mathrm{mg}$ in aliquot $\mathrm{x}$ total $\mathrm{ml}$ of Ash solution) / (volume of aliquot $\mathrm{x}$ weight of sample $)] \times 100$

\subsubsection{Statistical Analysis}

Samples were analysed in triplicate and the results were given as means \pm standard deviation. Oneway ANOVA and the student's $t$-test, both packaged in the GraphPad Prism for Windows Version 6.0 and the Statistical Package for Social Sciences (SPSS) for Windows Standard Version 8.0.0 were used for the statistical evaluation, with $\mathrm{P}<0.05$ considered statistically significant.

\subsection{RESULTS AND DISCUSSION}

\subsection{Nutritional composition}

Results of the analyses done to determine the macro-nutritional and selected mineral content of the cereal grains are shown in table 3.1. The crude protein, crude fat, fibre, ash, calcium and phosphorus were determined.

Table 3.1: Results of proximate composition analyses on samples of selected cereal grains and expressed as a percentage of the dry weight. Values are mean \pm standard deviation of triplicate determinations. ${ }^{D}$ was used to indicate domesticated cereal grain. ND indicates that the component investigated was not detected

\begin{tabular}{|c|c|c|c|c|c|c|}
\hline Sample & Calcium & Phosphorus & Ash & $\begin{array}{l}\text { Ether } \\
\text { Extract }\end{array}$ & $\begin{array}{l}\text { Crude } \\
\text { Protein }\end{array}$ & $\begin{array}{l}\text { Crude } \\
\text { Fibre }\end{array}$ \\
\hline Amaranthus hybridus & $0.68 \pm 0.01$ & $0.86 \pm 0.02$ & $2.16 \pm 0.02$ & $11.50 \pm 0.03$ & $21.44 \pm 0.05$ & $5.78 \pm 0.01$ \\
\hline Brachiaria brizantha & $0.06 \pm 0.02$ & $0.19 \pm 0.04$ & $8.94 \pm 0.01$ & $4.13 \pm 0.03$ & $8.24 \pm 0.01$ & $30.43 \pm 0.01$ \\
\hline Panicum maximum & $0.14 \pm 0.05$ & $0.31 \pm 0.03$ & $13.16 \pm 0.09$ & $4.65 \pm 0.05$ & $12.82 \pm 0.03$ & $26.03 \pm 0.06$ \\
\hline $\begin{array}{l}\text { Rottiboellea } \\
\text { cochinchinensis }\end{array}$ & $0.20 \pm 0.03$ & $0.20 \pm 0.02$ & $8.37 \pm 0.05$ & $4.70 \pm 0.01$ & $6.83 \pm 0.03$ & $24.89 \pm 0.09$ \\
\hline Sorghum arundinaceum & $0.19 \pm 0.07$ & $0.26 \pm 0.01$ & $7.38 \pm 0.06$ & $3.04 \pm 0.01$ & $10.66 \pm 0.04$ & $12.40 \pm 0.05$ \\
\hline Eleusine corocana ${ }^{\mathrm{U}}$ & $0.21 \pm 0.02$ & $0.19 \pm 0.01$ & $3.05 \pm 0.07$ & $2.04 \pm 0.03$ & $4.57 \pm 0.06$ & $3.52 \pm 0.04$ \\
\hline Sorghum bicolor & ND & $0.24 \pm 0.04$ & $2.28 \pm 0.01$ & $3.32 \pm 0.02$ & $7.84 \pm 0.02$ & $2.51 \pm 0.07$ \\
\hline
\end{tabular}


The nutritional and mineral content differed significantly $(p<0.05)$ among the cereal grain. In order to contextualize the importance of the nutrient data obtained from the nutritional analyses of selected wild cereal grains used as plant foods, a comparison of the nutritional data was done with that of domesticated grains that are consumed traditionally by the inhabitants of the semi-arid regions of Zimbabwe during times of severe droughts [22]. The domesticated grains used for the comparisons are eleusine corocana and the red variety of sorghum bicolor.

\subsubsection{Protein}

The protein content of five (5) wild cereal grains and two (2) domesticated and commercial grains is shown in table 3.1 . The order starting with the cereal grain with the most protein percentage content is as follows: $A$. hybridus $>P$. maximum $>S$. arundinaceum $>$ B. brizantha $>S$. bicolor $(r e d)>R$. cochinchinensis $>$ E. corocana.

Amaranthus hybridus, a wild cereal grain, was shown to contain a protein concentration of $21.44 \%$ which is higher than most traditionally consumed grains with the exception of soya beans [7]. The protein composition of some traditional cereal grains like wheat is $14 \%$, soybeans $37 \%$, rice $7 \%$ and maize with $9 \%$ according to O'Brien and Price (2008) [29]. The percentage of protein content in other relatives of Amaranthus hybridus like Amaranthus cruentus was reported to be about $16.2 \%$ [16] and $17.9 \%$ in Amaranthus hypochondriacus seeds [3].

Cereal grains are the most abundant and available source of nutrition throughout the world [1]. In third world countries like Zimbabwe, cereals are almost entirely the source of nutrition for the poorest families. The dependents on cereals, of the poor families, accounts in part, for the protein deficiency which dominates amongst the general population as recognized by Food and Agricultural Organization [13] significantly high protein content in wild cereals which include, A. hybridus, S. arundinaceum and P.maximum, compared to domesticated varieties, Eleusine corocana and red Sorghum bicolor $(p<0.05)$, is a result that provides a lead to alternative protein sources.

The protein content in $A$. hybridus of $21.44 \%$ which is significantly higher $(p<0.05)$ than that of commercial wheat with 12 $16 \%$ protein [23], makes the amaranthus flour potentially utilizable in the food industry. However, further research into the protein quality is of great importance in order to be able to safely recommend the effective use of the cereal grains.

\subsubsection{Fibre}

Measurements of dietary fibre are vital to the assessment of potential beneficial and preventive effects of fiber intake. $B$. brizantha was found to contain significantly $(p<0.05)$ higher content of crude fibre $(30.44 \%)$, followed by $P$. maximum $(26.03 \%)$ and $R$. cochinchinesis (24.89\%). The high fibre content in the cereal grains can be used to fortify food products with low fiber composition in order to enhance digestion in the humans. A high fibre diet can help lower cholesterol, control blood sugar mainly if soluble fibre, prevent constipation and helps in bulking excreta if fibre is insoluble [12].

All of the wild cereal grains had significantly high fiber content than the selected domesticated cereal grains $(p<0.05)$. The red variety of $S$. bicolor had the least crude fiber content of $2.51 \%(p<0.05)$ followed by $E$. corocana $(3.52 \%)$ and $A$. hybridus $(5.78 \%)$ respectively in increasing order.

The recommended daily allowance (RDA) of total fibre intake for the Americans is $25-35 \%$ [25]. The 5.78\% crude fibre content determined for $A$. hybridus effectively meant that for every 100 grams of amaranthus sample, 5.78 grams was crude fibre. So for an individual to consume fibre that is within the RDA range, one would need to consume at least 500 grams of the $A$. hybridus daily.

\subsubsection{Fat}

The fat content of wild and domesticated cereal grains are shown in table 3.1. The fat content in Amaranthus hybridus of $11.5 \%$, was significantly higher $(p<0.05)$ than the other grains studied which had values ranging from $2.04 \%-4.7 \%$. The fat content found in Amaranthus hybridus was significantly $(\mathrm{p}<0.05)$ higher than in some cereals reported by Sinclair and O'Dea [24]. Sinclair and O'Dea [24] reported that cereals were low in fats averaging 3.6\% fat for their total caloric content. Plant fat contains essential fatty acids that humans cannot synthesise, and must be acquired through diet. Essential fatty acids are long chain polyunsaturated fatty acids derived from linolenic, linoleic, and oleic acids and are necessary for the formation of healthy cell membranes, the proper development and functioning of the brain and nervous system [8]. A predominantly cereal- and plant-based diet could contribute $5-10 \mathrm{~g}$ per person per day of linoleic acid (LA), the major $\Omega-6$ polyunsaturated fatty acid found in grains [24].

\subsubsection{Minerals: Calcium and Phosphorus}

The levels of calcium and phosphorus in the selected wild and domesticated cereal grains are shown in Table 3.1 . Calcium is the most abundant element in the human body by mass and 99 per cent of the element is found in the bones and teeth. Some of the calcium is essential for the contraction of heart and other muscles, of nerve and enzyme functions and for blood clotting. Calcium content was highest in Amaranthus hybridus (0.68\%) and lowest in Brachiaria brizantha with $0.06 \%$ calcium. The element was not detected in the sorghum bicolor grain sample used for this research and this result was unusual and inconsistent with values reported by other researchers for the same grain. 
The lack of calcium in the amaranth seeds may have been because calcium uptake by the plant is passive and does not require energy input. The movement of calcium in the plant takes places mainly in the xylem, together with water. Therefore uptake of calcium is directly related to the transpiration rate of the plant, so conditions of high humidity, cold and a low transpiration rates may result in calcium deficiency [6]. The amaranth seeds were collected during the rainy season where humidity levels were high, so the calcium content may have been affected. Salinity build-up might have also caused calcium deficiency because it decreases the water uptake by the plant, but however, further investigations may be needed to ascertain the cause of calcium deficiency in the amaranth seeds. One other factor that may have affected the calcium levels is the soil $\mathrm{pH}$. Usually soils that have a lower $\mathrm{pH}$ level contain less available calcium [6].

Phosphorus is after calcium, the most abundant mineral element in the body. It is found in bones and teeth and in cellular fluids. It plays an essential function in the liberation and utilization of energy in animal and vegetable tissue and therefore is widely distributed in all foods. Amaranthus hybridus (0.86\%) seemed to have the highest phosphorus content, but statistically, the difference in the phosphorus content between all the grains studied was not significant $(p<0.05)$.

The mineral values reported here were significantly lower for both calcium and phosphorus $(p<0.05)$ compared to what was reported by Milton and co-workers who determined mineral concentrations in 16 species of wild and 4 species of cultivated fruits in American Samoa [17].

Chitindingu and colleagues in 2007 reported high levels of phenolic compounds in the cereal grains that were. The presence of high levels of phenolic compounds such as proanthocyanidins has adverse effects on mineral composition of cereals. Higher molecular weight phenolic compounds bind and form complexes with divalent ions [27]. The high content of phenolic compounds in all the cereal grains studied may have contributed to lowering the concentrations of minerals. For Amaranthus which was collected during the rainy season, the high rainfall may have leached the calcium and the leaching may have contributed to the low content in calcium [26].

A low $\mathrm{Ca} / \mathrm{P}$ ratio can reduce the growth of bones and metabolism of the animal consuming the cereal. The recommended, ideal $\mathrm{Ca} / \mathrm{P}$ ratio for humans and animals when they consume foods is $1: 1$, whereas in the United States where a study was carried out by Calvo [4] in 1993, the Ca/P ratio averages 0.64 for women and 0.62 for men. The $\mathrm{Ca} / \mathrm{P}$ ratios of the cereal grains are shown in table 3.2. S. bocolor, B. Brizantha and $P$. maximum had significantly lower $(p<0.05)$ ratios when compared with the other cereal grains studied. Consumption of excess dietary phosphorus, when calcium intake is adequate or low, leads to secondary hyperparathyroidism and progressive bone loss [4]. Therefore one would need to supplement the intake of calcium if $\mathrm{Ca} / \mathrm{P}$ ratio is low.

The net effect of low calcium content and a low $\mathrm{Ca} / \mathrm{P}$ ratio is the induction of bone mineral pathologies in populations like the poor in Zimbabwe, reliant entirely upon cereal grains as their only source of nutrition [2; 10; 21].

Table 3.2: The Ca/P ratio of selected wild and domesticated cereal grains. ${ }^{\mathrm{D}}$ was used to indicate domesticated cereal grains.

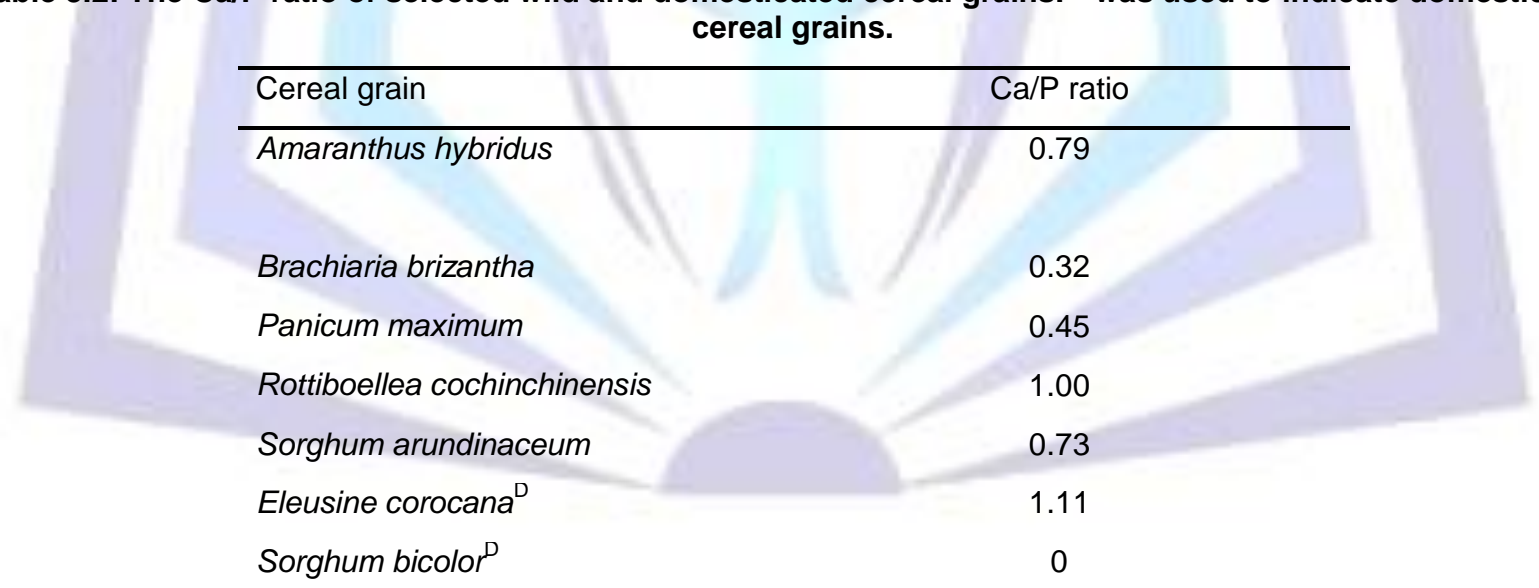

\subsection{CONCLUSIONS}

Wild cereal grains are potential alternative nutrition sources. All the cereal grains had valuable nutrients and with further research on the bioaccessibility of the nutrients, the cereals can be an alternative food source in Zimbabwe. Proteins and fats were found in varying concentrations in all the cereal grains. The protein and fat content in Amaranthus hybridus was high and this makes amaranthus a good source of protein and fat compared to all the cereal grains that were studied. Fibre was found in varying concentrations in the cereal grains, but the high content of fibre in Brachiaria brizantha can render it a suitable fortification cereal for foods with low fibre content. The minerals calcium and phosphorus, that are important for human health, were detected in the cereal grains. 


\section{ACKNOWLEDGMENTS}

We wish to thank the WF Kellog's Foundation, UNU-INRA and the University of Zimbabwe research board for funding this project.

\section{REFERENCES}

[1] Akubugwo, I.E., Obasi, N.A., Chinyere, G.C., and Ugbogu, A.E. (2007). Nutritional and chemical value of Amaranthus hybridus L. leaves from Nigeria. Afr J Biotechnol; 6 (24): 2833-9.

[2] Berlyne. G.M., Ben Ari, J., Nord, E., and Shainkin, R. (1973). Bedouin osteomalacia due to calcium deprivation caused by high phytic acid content of unleavened bread. Am J Clin Nutr., 26:910-911.

[3] Cai, Y.Z., Corke, H., Wu, H.X. (2004). Amaranth. In Encyclopedia Grain Sci. 6. ISBN 978-0-12-765490-4.

[4] Calvo, M.S. (1993). Dietary phosphorus, calcium metabolism and bone. J Nutr 123:1627-1633.

[5] Chitindingu, K., Ndhlala A.R., Chapano, C., Benhura, M.A. and Muchuweti M (2007). Phenolic compound content, profiles and antioxidant activities of Amaranthus hybridus (Pigweed), Brachiaria brizantha (Upright brachiaria) and Panicum maximum (Guinee grass). J. Food Biochem., 31, 206-216.

[6] de Freitas, S.T. and Mitcham. E.J. (2012). Factors Involved in Fruit Calcium Deficiency Disorders. Reviews, Volume 40, First Edition. Edited by Jules Janick

Horticultural

[7] Dhellot, J.R., Matouba, E., Maloumbi, M. G., Nzikou, J.M., Ngoma Safou, D. G., Linder, M., Desobry, S., and Parmentier, M (2006). Extraction, chemical composition and nutritional characterization of vegetable oils: Case of Amaranthus hybridus (Var 1 and 2) of Congo Brazzaville. J. Biotechnol., 5 (11): 1095-1101.

[8] Ercisli, S. and Orhan, E. (2007). Chemical composition of white (Morus alba), red (Morus rubra) and black (Morus nigra) mulberry fruits. Food Chem., 103: 1380-1384.

[9] Food and Agricultural Organisation (FAO). (1995) www.fao.org/es/faodef/fdef01e.htm

[10] Ford, J.A., Colhoun, E.M., McIntosh, W.B. and Dunnigan, M.G. (1972). Biochemical response of late rickets and osteomalacia to a chupatty-free diet. $\mathrm{Br}$ Med J., 2:446-447.

[11] Jacobs J.R. and D.R. Gallagher. (2004). Whole grain intake and cardiovascular disease: a review. Current Atherosclerosis Reports 6: 415-423.

[12] Johnson, I. (2004). New approaches to the role of diet in the prevention of cancers of the alimentary tract. Mutation Research., 551: 9-28.

[13] Ladeji, O., Okoye, Z.S. and Ojobe, T. (1995). Chemical evaluation of the nutritive value of leaf of fluted pumpkin (Telferia occidentalis). Food Chem., 53: 353-355.

[14] Larsson, S.C., E. Giovannucci, L. Bergkvist and A. Wolk. (2005). Whole grain consumption and risk of colorectal cancer: a population-based cohort of 60,000 women. Br. J. Cancer., 92: 1803-1807.

[15] Manach, C., Scalbert, A., Morand, C., Rémésy, C. and Jimenez, L. (2004). Polyphenols: food sources and bioavailability. Am J Clin Nutr., 79:727- 47.

[16] Mendoza, C.M. and Bressani, R. (1987). Nutritional and Functional Characteristics of Extrusion-Cooked Amaranth Flour. In Cereal Chem., 64 (4): 218- 22.

[17] Milton, K. (1999). Nutritional characteristics of wild primate foods: Do the diets of our closest living relatives have lessons for us? Nutr., 15 (6): 488-498

[18] Murtaugh, M.A., J.R. Jacobs, D.R. Steffen, L.M. Jacob and L.Marquart. (2003). Epidemiological support for the protection of whole grains against diabetes. Pro. Nutr Soc., 62: 143-149.

[19] Pereira, M.A., D.R. Jacobs, J.J. Pins, S.K. Raatz, M.D.Gross, J.L. Slavin and E.R. Seaquist. (2002). Effect of whole grains on insulin sensitivity in overweight hyper insulinemic adults. Am. J. Clin. Nutr., 7: 848-855.

[20] Pinchuck, T. (1996). The Rough Guide to Zimbabwe and Botswana. London: Viking Penguin.

[21] Robertson, I., Ford J.A., McIntosh W.B. and Dunnigan, M.G. (1981). The role of cereals in the aetiology of nutritional rickets: The lesson of the Irish national nutritional survey 1943-8. Br J Nutr., 45: 17-22.

[22] Shava, S. (2003). A Checklist of Wild Food Plants of Zimbabwe. National Herbarium and Botanic Gardern, Harare.

[23] Shewry, P.R. (2000). Seed proteins. In: Black M, Bewley JD, editors. Seed technology and its biological basis. Sheffield, UK: Sheffield Academic Press. p. 42-84.

[24] Sinclair, A.J. and O'Dea K (1990). Fats in human diets through history: Is the western diet out of step?; in Wood JD, Fisher AV (eds): Reducing Fat in Meat Animals. London, Elsevier Applied Science. pp 1-47. 
[25] Spiller, G. A. (1993). Suggestions for a basis on which to determine a desirable intake of dietary fibre. In: Spiller GA, ed. CRC Handbook of Dietary Fiber in Human Nutrition. CRC Press, Boca Raton, FL, pp. 351-354.

[26] Wall, M.M. (2006). Ascorbic acid and mineral composition of longan (Dimocarpus longan), lychee (Litchi chinensis) and rambutan (Nephelium lappaceum) cultivars grown in Hawaii. J. Food Comp. and Anal., 19: 655-663

[27] Wallace, G. and Fry, S.C. (1994). Phenolic components of the plant cell wall. Int Rev Cytol., 151:229-267.

[28] Yuan, H., Gong, A. And Young, C. Y. (2005). Involvement of transcription factor Sp1 in quercetin-mediated inhibitory effect on the androgen receptor in human prostate cancer cells. Carcin., 26: 793-801

[29] O'Brien, K.G. and Price, M.L. (2008). Amaranth Grain \& Vegetable Types. In Echo Technical note. 17391 Durrance Rd., North Ft. Myers, Florida, 33917. 